\title{
Geographical Indicators for Grapes
}

\author{
J. Tonietto \\ Brazilian Agricultural Research Corporation - Embrapa \\ National Center for Grape and Wine Research \\ Bento Gonçalves \\ Brazil
}

Keywords: climate, soil, terroir, wine typeness, Géoviticulture MCC System, geographical indication, just-in-time quality

\begin{abstract}
Whereas viticulture has been historically evolved in an empiric way, we are today confronted with a viticulture characterized more and more by technicality. The knowledge being increasingly complex and closer to interpreting the reality, viticultural zoning advances to answer more and more profound questions. Geographical indicators for grapes - soil, climate, adaptation of the grape varieties are one of the major contributions of viticultural zoning, which offers a whole range of practical applications. It is growing in importance, be it on account of the technical resources which are becoming more efficient and which make possible the development of an increasingly integrated, consistent and useful zoning, be it on account of a more and more globalized market. The article points out the importance of geographical indicators for table grape producing and for winegrowing regions. It deals with viticultural production, quality and typicity of the products with regards to their organoleptic characteristics. Some aspects of the contribution of zoning are detailed: site selection, the agroviticultural and enological management, the delimitation of the viticultural territories and zoning of regions with viticultural potential, including particularities of grape production in tropical regions. Methodologies for zoning studies are presented, such as the Géoviticulture Multicriteria Climatic Classification System; moreover, the text shows the indirect contributions regarding the table grape and wine market, the sustainable territory development and the possibility of the establishment of Geographical Indications in some cases. A new concept for some tropical wines is presented: the just-in-time quality.
\end{abstract}

\section{Résumé}

Indicateurs Géographiques en Viticulture

Mots-Clés : climat, sol, terroir, typicité, Système CCM Géoviticole, indications géographiques, marché, qualité just-in-time

L'importance du zonage vitivinicole, y compris les indicateurs géographiques, est en train d'augmenter, soit en fonction des moyens techniques chaque fois plus performants, qui rendent possible le développement des zonages de plus en plus intégrées, consistants et utiles, soit en fonction d'un marché de plus en plus mondialisé. Indicateurs géographiques pour la viticulture - sol, climat, adaptation des cépages, ce sont des contributions importantes du zonage vitivinicole, qui offre une série d'usages pratiques. Quelques aspects de la contribution du zonage sont particularisés : la gestion agroviticole et onologique, la délimitation des territoires viticoles et le zonage des régions à potentiel viticole, et également quelques particularités de la production dans les régions tropicales. Approches méthodologiques sont pressées, comme est le cas du Système CCM Géoviticole. L'article montre les contributions indirectes du zonage dans la production du raisin de table et du raisin de cuve au niveau du marché, et au niveau du développement territorial et du développement soutenible. La possibilité de valorisation des produits des régions de la zone intertropicale par les Indications Géographiques est signalée. Un nouveau concept pour quelques vins produits en zone tropicale est 
présenté : la qualité just-in-time.

\section{INTRODUCTION}

Whereas viticulture has been historically evolved in an empiric way, we are today confronted with viticulture, characterized more and more by technicality.

The knowledge being increasingly complex and closer to interpreting the reality, viticultural zoning, that includes geographical indicators, advances to answer more and more profound questions. Yesterday's zoning used to be simpler. Tomorrow, we will have much more complexity. In fact, resources to perform integrated zoning are augmenting; furthermore, the producers and the consumers' demands require this.

The zoning of viticultural terroirs can be seen as a kind of agro-ecological zoning. In the definition frame of geographical indication area, it is protection zoning (of a product), and as it contributes to the regional development, it is also management zoning (Vaudour, 2003). While zoning, one is challenged to understand the potential of the natural factors and their interaction with the human factors of which climate, soil, grape cultivar and agroviticultural as well as enological techniques are components of the products - table grapes and wines.

As a practical application, zoning can be placed in the center of the two major elements of viticulture: the production and the market.

The use of zoning as an instrument for the development of viticulture and for the valorization of a region's vocation is the major goal to be achieved in a manner that valorizes in space and time this millennial production, which is part of man's history.

\section{PRACTICAL APPLICATIONS OF GEOGRAPHICAL INDICATORS IN VITICULTURE}

To discuss the practical applications of viticultural zoning that includes geographical indicators for grapes, does not only mean to make visible everything that has been achieved up to the present time but also to open new paths to discover potential contributions of zoning.

The first great objective contribution of the practical application of zoning is linked to the viticultural and enological production (grape/wine), where the management of the viticultural space and the agroviticultural and enological management of this space are found; moreover, this contribution is related to the configuration of the production areas, which usually group several or even hundreds or thousands of winegrowers. In the regions productional organization, viticultural zoning is an effective instrument of contribution to the aspects of regional development (Tonietto, 2004). In fact, it affects the territorial development and has implications on the sustainable development (Fig. 1).

The second great contribution of zoning is related to all the aspects that are a consequence of zoning and that allow for the valorization of the products (table grape or wines) and the concerned territory (Tonietto, 2004). This practical use interests to the market, to the consumer. All the quality and typeness of table grapes and wines linked to the terroir, can be explored toward a differentiation of the production, a distinction that can be used to increase the competitiveness of the product on market level (Fig. 1).

The agroviticultural management is one of the most objective elements of zoning; to optimize the terroir effect, search the balance between the effects of the restraints of the environment and those of the favorable factors (Asselin, 2002). The terroir effect must be seen by the interaction with the grape cultivar which comprises the rootstock, cultivation methods - training system, dormant and herbaceous pruning, cluster thinning and cultivation practices at the soil level (Fig. 2). Also, the agroviticultural management should establish a connection with the enological management, which valorizes the potential of the grapes produced at the viticultural terroir. In this way, zoning is a helping instrument for the decision at the different stages of the table grape or wine-growing production (Tonietto, 2004). 


\section{GEOGRAPHICAL INDICATORS FOR QUALITY AND TYPICITY OF VITICULTURAL PRODUCTS IN THE WORLD}

Zoning has to be centered on the specific features of the region studied in order to better understand and exploit its potential for a production that is authentic and of good quality. The following examples show that viticultural zoning of a region is not something or arbitrary, but constitutes the comprehension and interpretation of the local reality with regard to the particular viticultural potential of each region.

\section{Macroclimatic Zoning of the Regions in California}

By means of the Thermic Index of Winkler, 5 wine growing regions in California were classified according only to the thermic characterization of their climate. The advantage of this climatic index is that it is very simple. It does not take into account the day length, which can be explained by the fact that, originally, it was only conceived for California, for rather low latitudes $\left(33^{\circ}\right.$ to $39^{\circ}$ latitude North), where this factor does not play a distinguishing role. In this large region, Amerine and Winkler (1944) show that too low or too high temperatures are related to a slight coloration. They observe the same tendency in relation to polyphenols. The Californian wines from the regions I, II and III contain more anthocyanins and polyphenols than those from the regions IV and V.

\section{Water Availability for Quality Wines in Bordeaux}

In Bordeaux, a region with ocean climate and without intense drought, the wine quality of different years is inversely correlated to the water balance of the vineyard. (Riou et al., 1994); however, the problem of water availability has a close relation to the role of the soil. Research studies that were carried out by Seguin, Duteau and Van Leewen in the vineyards of Bordeaux show that the regulation of water availability of the soil plays a key role in the quality potential of the grape. Regular water availability, at a rather low level, and above all, without any type of excess, seems to be a determining parameter of the wine quality. Experiments carried out in Saint-Émilion and in Pomerol show that, for a percentage of ETR in relation to ETP between $45 \%$ and $35 \%$, the decrease of water availability leads to an improvement of the grape quality (Seguin, 1983).

\section{Precocity of the Vine Cycle in Septentrional Vineyards}

Several studies (Morlat, 2001) have established that the precocity of the vine cycle plays an essential role in the explanation of the maturity level achieved at the harvest time, particularly in septentrional vineyards where the thermic and light conditions can become limiting from the beginning of fall on. Under these conditions, zoning designed to identify precocious and late "terroirs" is fundamental.

\section{Zoning in More Humid Regions}

In humid regions, excessive water is often a limiting factor to the grape quality. In this situation, the search for sub-regions with a more favorable distribution of rainfalls throughout the vegetative cycle should be considered. In the same way, there should be selected "terroirs" with good soil drainage in accordance to the necessities of the grapevine. This is often the case in some subtropical zones in South America.

\section{Searching for Less Hot Mesoclimates in South Africa}

Breezes blowing in the direction of sea-continent have an effect on the variation of the temperatures and the relative air humidity in the region of Stellenbosch. This atmospheric occurrence is being utilized for the identification of viticultural "terroirs" which present high humidity and cool temperatures during the maturation period of the grapes (Bonnardot et al., 2002).

\section{Zoning in Regions of Viticultural Climates with Intra-Annual Variability}

In the case of hot temperatures during the whole year, as in the tropical semiarid 
climate of the São Francisco Valley in the Northeast Region of Brazil, there exist 3 different viticultural climates throughout the year (more or less hot, more or less humid). Under these conditions, the wine quality is linked to the period of the year chosen for the grape production. In this situation, which is completely particular in the world's viticulture, it is necessary to integrate, in the same vineyard, climatic zoning with the zoning of the production period according to the intra-annual variability (Tonietto and Carbonneau, 1999). Figure 3 shows the 3 climate periods of viticultural interest during the year in Petrolina, São Francisco Valley in Brazil (Tonietto and Teixeira, 2004).

\section{Cool Night Temperature Related to the Typicity of Table Grapes in Vaucluse}

In the zone of the Denomination of Origin ("A.O.C."), Muscat de Ventoux region of Vaucluse, France - a Muscat de Hambourg of a very high quality is produced. The typicity of the region's Muscat lies in the intense black coloration and the intense and elegant muscat flavor. On the contrary to other zones of this region, the berries are insufficiently colored and do not have the typical flavor of the muscat produced in the zone of Ventoux.

Through mesoclimatic zoning, the minimum air temperature during the veraisonharvest period has been identified (which corresponds to the utilization of the Cool Night Index of the Géoviticulture Multicriteria Climatic Classification System, calculated over the bioclimatic maturation period of the grape) as a climatic factor. This factor distinguishes the zone of the Denomination of Origin Muscat du Ventoux in relation to other criteria and other viticultural zones of the Vaucluse region. Mesoclimatic zoning allows the classification of the zones into 5 different climatic categories, as a climatic criterion of quality and typicity of the zone where the Denomination of Origin is produced (Tonietto and Carbonneau, 1998).

\section{Regional Quality and Typicity of Varietal Wines in Brazil}

Tonietto et al. (2005) have demonstrated the selection of varieties of higher quality for each region according to the sensorial expressions of wines derived from different interactions "cultivar x environment". The typicity of wines of 13 cultivars is expressed in a particular way in each of the 3 studied regions in South Brazil (Vale dos Vinhedos, Serra do Sudeste and Campanha). This can be exploited as to valorize the most typical wines and the wines of the highest quality on the consumers' market. Among the white wines, the Campanha presents more varietal typicity for Gewürztraminer, Italic Riesling and Ugni Blanc. In the Serra Gaúcha and the Serra do Sudeste, Chardonnay and Sémillon are more typical. Among the white wines, the Rhénan Riesling is the variety with less varietal typicity in all the regions. Among the red wines, Cabernet Franc is the most typical in the Serra Gaúcha and Cabernet Sauvignon in the Serra do Sudeste. Gamay wine presents the least varietal typicity in the 3 regions.

\section{METHODOLOGICAL ELEMENTS OF ZONING}

For the purpose of identifying geographical indicators for the quality and typicity of the products, the natural environment can be analyzed through different approaches: climatic approach, pedologic approach, viticultural approach based on the study if the interaction between genotype $\mathrm{x}$ environment, environmental structure approach (using informatics as tool), and integrated or multicriteria approach.

Before choosing a methodology and criteria for viticultural zoning, one has to understand which natural factors (geographical indicators) have an effect on quality and typicity of the viticultural products in the environment in which the viticultural zoning is going to be performed.

It is still possible to discuss zoning in view of the search of new regions with a viticultural potential. This is of special concern to countries of the new world viticulture that searches for new frontiers of production areas. In this case, zoning represents the means for analyzing the potential of the environmental factors, be it the restraints or the conditions of inaptitude for viticulture, or be it the evaluation of the potential quality of 
the terroirs. In this situation, zoning can give answers to several questions on the potential of the climate and the soil for viticulture of quality (Tonietto, 2004) (Fig. 4).

There are many methodologies for zoning. As global classification system have interest for it's use in spatially defined generalization of viticultural data, in order that distinct vine environments could be compared worldwide, it's recommended to use methodologies reference with this characteristics: Géoviticulture Multicriteria Climatic Classification System (Géoviticulture CCM System), for world viticulture (Tonietto, 1999, 2003; Tonietto and Carbonneau, 2004); soil data system as described by the World FAO (ISSS, 1998); training systems (Carbonneau and Cargnello, 2003), etc.

\section{GI AND JUST-IN-TIME QUALITY CONCEPT FOR WINES OF THE INTERTROPICAL ZONE}

\section{Geographical Indications}

Particularly, at the level of geographical indications - GI (concept that includes denomination of origin) and other means of terroir valorization, viticultural zoning can be an instrument for effective contribution to the territorial and sustainable local development.

Occasionally, the natural difficulties of a region (relief, etc.) can be transformed into an advantage and an aid for keeping the wine growers in their rural areas.

Zoning is an instrument for understanding and characterizing the wine produced under a multitude of interactions between natural conditions and the human know-how. It is, thus, an instrument for valorizing and maintaining the diversity of wines and the regional culture on a globalized market.

Zoning is fundamental for strategic studies of the viticultural production and of the market. Regional, differentiated and identifiable products allow placing the production in the context of globalization of trade. Zoning can valorize the typeness and authenticity of the terroirs by means of the wine and contribute to an adequate organization of the production and differentiation of the quality, to distinguish the products by quality signs linked to the origin of the production. Additionally, to increasing the competitiveness of the wine products, zoning allows to improve their traceability and the food safety.

In a world where the trade relations become more and more globalized, viticultural zoning can help to identify and maintain the great diversity of wine production, a basic element of its cultural wealth in the different regions of the world.

The development of geographical indications for wines of differentiated quality produces in the intertropical zone can be an important element for the organization of the production and for the differentiation and valorization of the products on the market. In fact, these products result from a new viticulture, new in terms of natural factors, of vine growing practices and of enology. They display distinctive organoleptic characteristics in comparison to those obtained by the traditional viticulture in temperate zones.

\section{Just-in-Time Quality Concept for Tropical Regions}

In zones where the grape and wine production is possible all over the year, like in the São Francisco Valley, Brazil, a new concept in wine market may be established: the "just-in-time quality wines".

This concept can be applied to quality and typeness wine production linked to the origin of the product, with regular production and supplying to the market all over the year. Wines like "nouveau" style or sweet muscat sparkling wines, where better organoleptic characteristics and quality for optimal consumption are related to a relatively short period between elaboration and consumption (normally some months from its elaboration), may take advantage of this new concept for the tropical regions.

\section{ACKNOWLEDGEMENTS}

To FINEP - Research and Projects Financing, for the financial support of the development research project. 


\section{Literature Cited}

Amerine, M.A. and Winkler, A.J. 1944. Composition and quality of musts and wines of California grapes. Hilgardia 15:493-673.

Asselin, C. 2002. Le groupe d'experts zonage vitivinicole de l'Office International Vigne et Vin - O.I.V.: ses activités, ses travaux. In: IV Symposium International sur le Zonage Vitivinicole, 4, 2002, Avignon, France. Compte Rendu. Avignon, Inter Rhône et Office International de la Vigne et du Vin. pp.539-551. (Tome II).

Bonnardot, V., Planchon, O., Carey, V. and Cautenet, S. 2002. Diurnal wind, relative humidity and temperature variation in the Stellenbosch-Groot Drakenstein winegrowing area. S. African J. Enol. Vitic. 23:62-71.

Carbonneau, A. and Cargnello, G. 2003. Architectures de la vigne et systèmes de conduite. Dunod, Paris.

International Society of Soil Science (ISSS). 1998. World Reference Base for Soil Resources. 84 World Soil Resources Report. FAO, ISRIC and ISSS, Rome.

Morlat, R. 2001. Terroirs viticoles: étude et valorisation. Chaintré, Avenir Enologie. p. 118 .

Riou, C., Becker, N., Sotes Ruiz, V., Gomez-Miguel, V., Carbonneau, A., Panagiotou, M., Calo, A., Costacurta, A., Castro, R., de Pinto, A., Lopes, C., Carneiro, L. and Climaco, P. 1994. Le déterminisme climatique de la maturation du raisin: application au zonage de la teneur en sucre dans la communauté européenne. Luxembourg, Office des Publications Officielles des Communautés Européennes. p.322.

Seguin, G. 1983. Influence des terroirs viticoles sur la constitution et la qualité des vendanges. Bull. de l'O.I.V. 623:3-18.

Tonietto, J. 1999. Les macroclimats viticoles mondiaux et l'influence du mésoclimat sur la typicité de la Syrah et du Muscat de Hambourg dans le sud de la France: méthodologie de caractérisation. Montpellier, École Nationale Supérieure de Agronomie - ENSA-M. p.233. (Thèse de doctorat).

Tonietto, J. 2003. Zonificacion Viticola: metodología de implementación y herramientas del sistema CCM Geovitícola. p.1-22. In: Curso Internacional de Vitivinicultura, 2003, Neuquén. Memoria Técnica. Neuquén, Instituto Nacional de Tecnologia Agropecuária - INTA.

Tonietto, J. 2004. Practical applications of viticultural zoning. p. 129-138. In: Joint International Conference on Viticultural Zoning, 15 a 19 nov. 2004, Cape Town, South Africa. CD Rom.

Tonietto, J. and Carbonneau, A. 1998. Facteurs mésoclimatiques de la typicité du raisin de table de l'A.O.C. Muscat du Ventoux dans le Département de Vaucluse. Progr. Agric. Vitic. 15:271-279.

Tonietto, J. and Carbonneau, A. 1999. Análise mundial do clima das regiões vitícolas e de sua influência sobre a tipicidade dos vinhos: a posição da viticultura brasileira comparada a 100 regiões em 30 países. In: Congresso Brasileiro de Viticultura e Enologia, 9., 7 a 10 de dezembro de 1999, Bento Gonçalves. Anais. Bento Gonçalves: Embrapa Uva e Vinho/Jorge Tonietto e Celito C. Guerra, ed. p.75-90.

Tonietto, J. and Carbonneau, A. 2004. A multicriteria climatic classification system for grape-growing regions worldwide. Agricultural and Forest Meteorology 124(1-2):8197.

Tonietto, J. and Teixeira, A.H.C. 2004. Zonage climatique des periodes viticoles de production dans l'année en zone tropicale: application de la méthodologie du Sistème CCM Géoviticole. p.193-201. In: Joint International Conference On Viticultural Zoning, 15 a 19 nov. 2004, Cape Town, South Africa. CD Rom.

Tonietto, J., Zanus, M.C. and Taffarel, J.C. 2005. Quality and typicity of wines from wine-growing regions of Rio Grande do Sul, Brazil: effect of agronomical characteristics of the vine. In: Gesco Meeting, 23 to 27 Aug 2005, Geisenheim, Germany. Proceedings. Gesco/Univ.Geisensheim. v.2. p.642-647.

Vaudour, E. 2003. Les terroirs viticoles : définitions, caractérisation et protection. Paris, Dunot. p.294. 


\section{Figures}

\section{VITICULTURAL ZONING \\ Practical Applications}

\section{AT THE LEVEL OF PRODUCTION AND DEVELOPMENT}

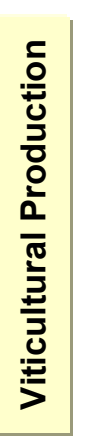

\section{Management of the viticultural} space (terroir selection)

Agroviticultural Management (cultural techniques)

Enological Management

Geographical Indications (delimitations/management)

\section{$Z O N \quad N \quad N G$}

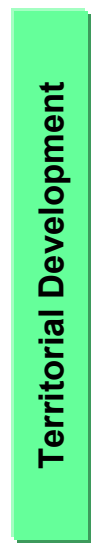

Restructuration of the Vineyards

Sustainable Development

Environmental Protection

Territorial Development
AT THE MARKET LEVEL
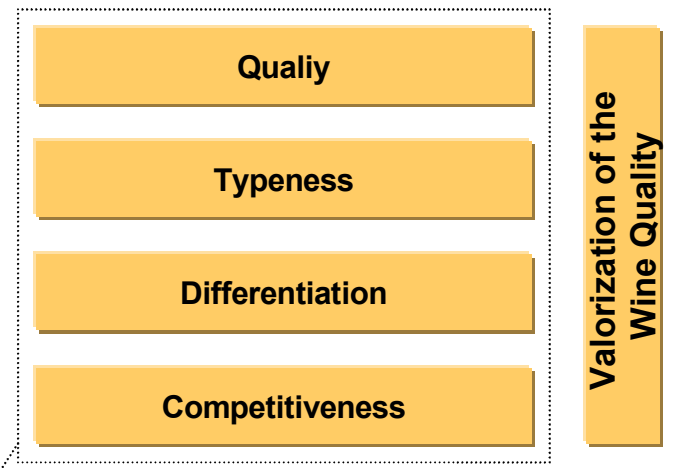

munication and Trade Strategy (marketing)

Value Addition to the Wines

Geographical Indications (valorization)

Valorization of the Landscape

Development of the Enoturism

\section{Géoviticultural Follow-Up}

Fig. 1. Practical applications of zoning connecting with the viticultural production, with the territorial development and with the valorization of the wine and the territory at the market level (Tonietto, 2004). 


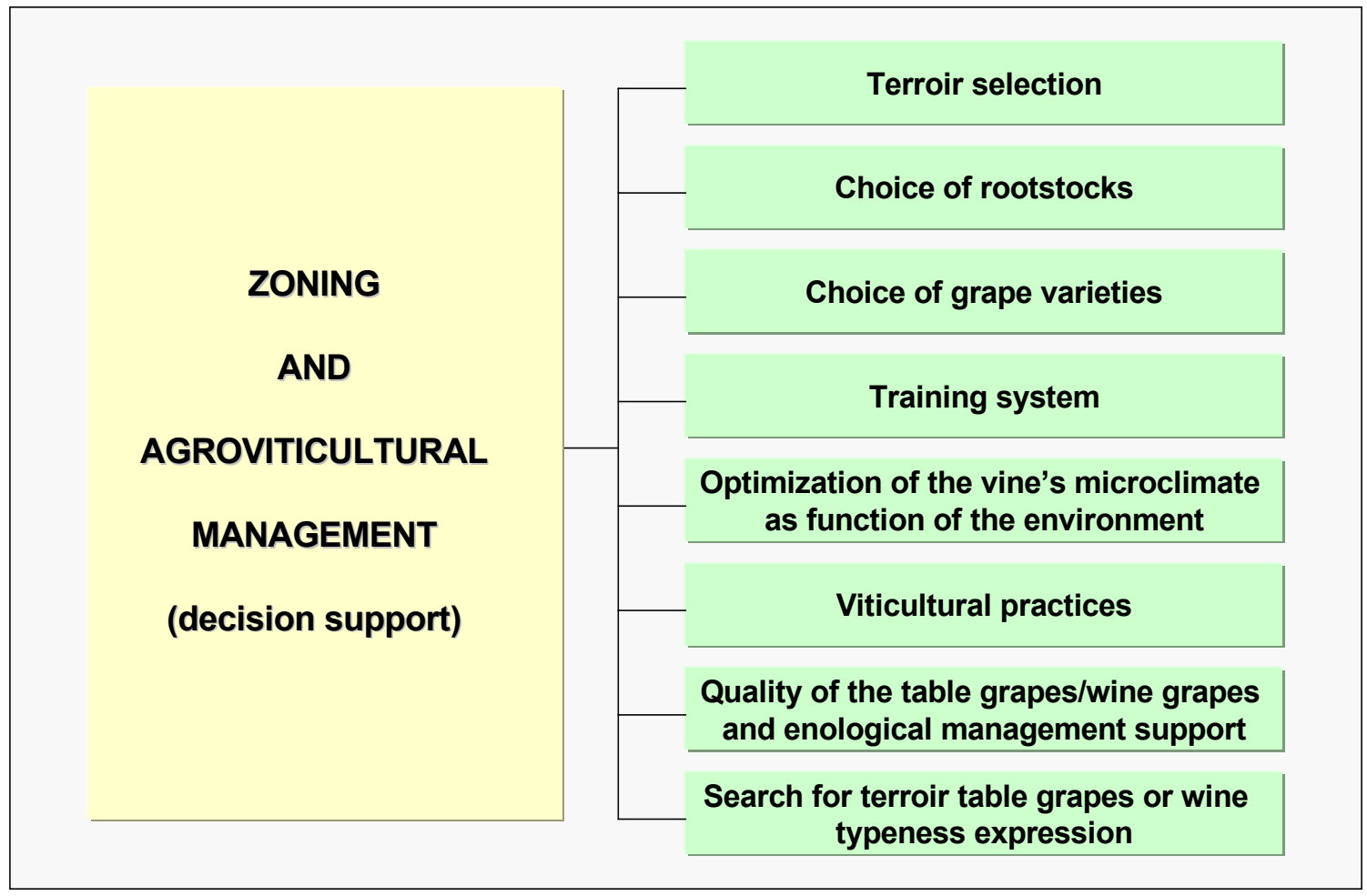

Fig. 2. Contribution of zoning to the agroviticultural management (Tonietto, 2004). 


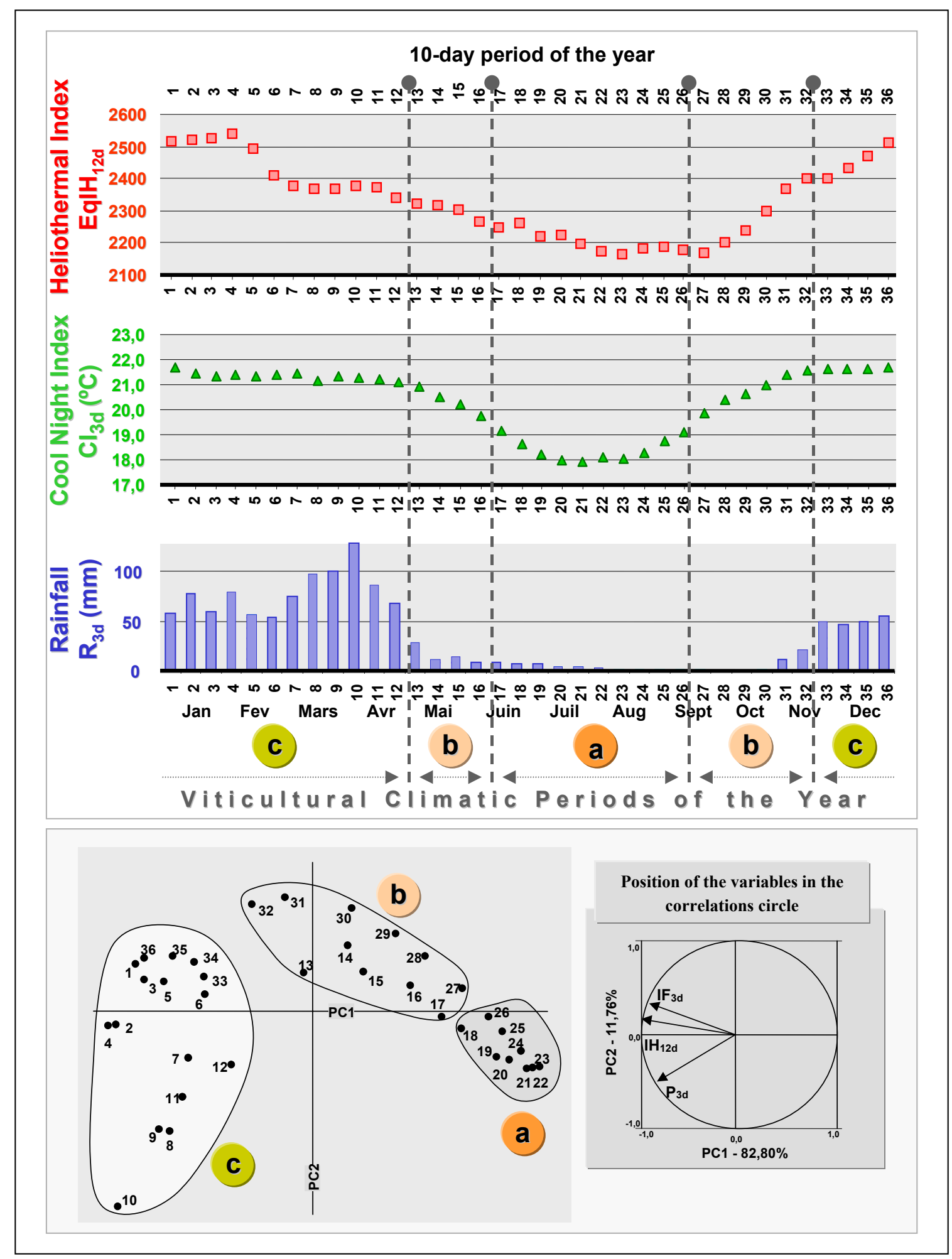

Fig. 3. Climatic index $-\mathrm{HI}_{12 \mathrm{~d}}$ (total $\mathrm{HI} 120$ days before harvest), $\mathrm{CI}_{3 \mathrm{~d}}$ (mean minimal temperature 30 days before harvest) and $\mathrm{R}_{3 \mathrm{~d}}$ (total rain 30 days before harvest), by 10-day period and viticultural climatic periods of the year at Petrolina, São Francisco Valley, Brazil: the P.C.A. group the periods "a", "b" and "c" (Tonietto and Teixeira, 2004). 


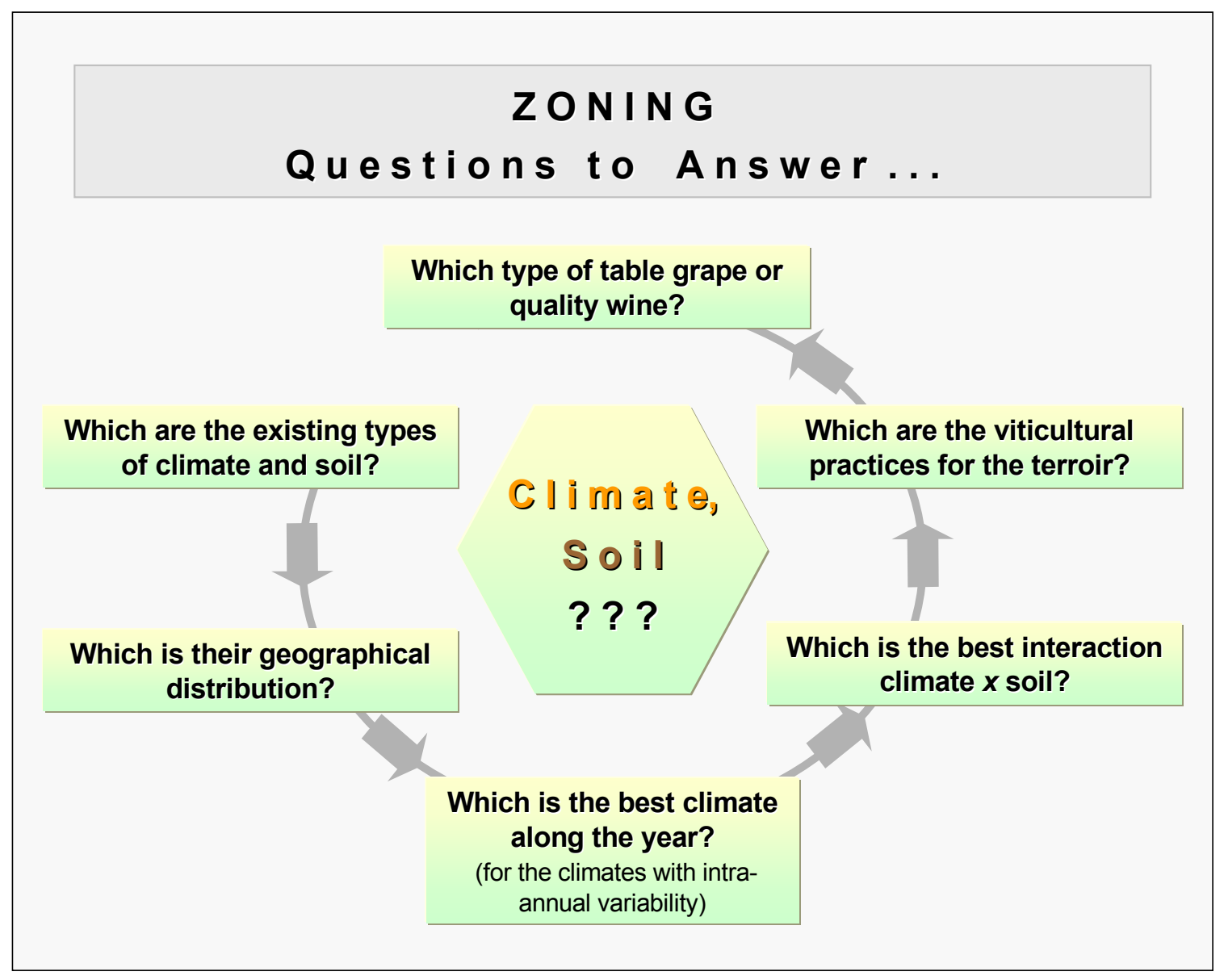

Fig. 4. Questions which zoning can answer about the potential of the climate and the soil for a regional viticulture of quality (Tonietto, 2004). 